\title{
Analisa Keruntuhan Bendungan Kering Ciawi Menggunakan Program HEC-RAS dan InaSAFE
}

\author{
Fabian Raditya Pramana $^{1 *}$, Pitojo Tri Juwono ${ }^{1}$, Runi Asmaranto ${ }^{1}$ \\ ${ }^{1}$ Jurusan Teknik Pengairan, Fakultas Teknik, Universitas Brawijaya, \\ Jalan MT. Haryono No. 167, Malang, 65145, INDONESIA \\ *Korespondensi Email: fabianprams@ student.ub.ac.id
}

\begin{abstract}
Dam is a structure built across a stream to retain water for the purpose of water supply, irrigation, hydropower, and flood control. Beside the high benefits, dams are also a potential threat to public safety, which is dam break/dam failure. The purpose of this study was to discover various scenarios of dam break at Ciawi Dam, with the main modes of failure have been identified as piping or overtopping. Ciawi dam break are modeled and analyzed using HEC-RAS v5.0.7 based on available geometry data. After that, based on regional population data, the economic loss calculated using InaSAFE. The simulation results showed that the Probable Maximum Flood (PMF) with a peak discharge of 1845,867 m³ $/ \mathrm{s}$ did not generate an overtopping scenario. From the analysis of 2-D simulation in HEC-RAS, the Ciawi dam break due to piping at Probable Maximum Flood (PMF) has a maximum water depth of 46,419 $\mathrm{m}$ with the area of inundation covers $108,04 \mathrm{~km}^{2}$. Those numbers imply that Ciawi Dam break classified as a high-hazard category.
\end{abstract}

Keywords: ciawi dam, dam break, flood

Abstrak: Bendungan adalah struktur yang dibangun melintang suatu aliran guna membendung air dengan tujuan sebagai penyedia air, irigasi, pembangkit listrik, dan pengendali banjir. Namun di samping manfaatnya yang besar, bendungan juga berpotensi membahayakan keamanan publik berupa keruntuhan bendungan. Tujuan studi ini adalah menganalisis berbagai macam skenario keruntuhan bendungan pada Bendungan Ciawi. Sebab utama keruntuhan diidentifikasi sebagai akibat dari piping atau overtopping, walaupun dalam kenyataan mekanisme keruntuhan tidak dapat diprediksi secara akurat. Keruntuhan Bendungan Ciawi disimulasikan dan dianalisis menggunakan HEC-RAS v5.0.7 dengan basis data geometri, kemudian dihitung kerugian ekonominya dengan bantuan InaSAFE. Hasil simulasi menunjukkan puncak debit banjir rancangan Qinflow PMF sebesar 1845,867 m³/detik tidak mengakibatkan skenario overtopping. Dari hasil analisis simulasi 2-D pada HEC-RAS, keruntuhan Bendungan Ciawi oleh skenario piping pada banjir PMF memiliki ketinggian air maksimum 46,419 m dengan luasan banjir melingkupi 108,04 km². Hal ini dapat diartikan bahwa banjir akibat keruntuhan Bendungan Ciawi dikategorikan sebagai bahaya tingkat tinggi.

Kata kunci: banjir, bendungan ciawi, keruntuhan bendungan 


\section{Pendahuluan}

Wilayah DKI Jakarta yang sering dilanda bencana banjir bukan merupakan hal yang baru. Karena sejatinya DKI Jakarta secara geologis merupakan cekungan banjir, dan secara geomorfologi merupakan dataran banjir yang terbentuk akibat proses sedimentasi ketika terjadi banjir [1]. Oleh karena itu, untuk menurunkan risiko bencana banjir, pemerintah membangun infrastruktur pengendali banjir berupa Bendungan Ciawi [2]. Bendungan Ciawi yang difungsikan sebagai dry dam diharapkan dapat mengendalikan limpasan hujan di perkotaan dengan cara meredam debit puncak dan kedalaman aliran di sistem sungai.

Ini tidak dapat dipungkiri, bahwa di samping manfaatnya yang besar, setiap pembangunan bendungan juga menimbulkan risiko yang besar pula [3]. Risiko tersebut berupa keruntuhan/kegagalan bendungan sehingga air dalam jumlah besar yang tersimpan di waduk dapat mengakibatkan banjir yang cepat dan tiba-tiba. Dampaknya, banyak nyawa yang terancam serta kerugian material yang tidak dapat dihindari. Tentu ditambah fakta bahwa Bendungan Ciawi dibangun atas material timbunan, bendungan tipe ini adalah yang paling sering terjadi kerusakan bendungan [4].

Wajib bagi seorang insinyur memperhatikan kemungkinan risiko terjadinya keruntuhan bendungan. Maka studi ini dilakukan untuk menganalisis skenario seperti apa yang dapat menyebabkan keruntuhan Bendungan Ciawi. Dari beberapa gambaran kemungkinan banjir akibat keruntuhan bendungan, akan dilihat dampak yang paling berpengaruh terhadap wilayah di hilir bendungan. Hal ini dapat dijadikan masukan, berapa estimasi nilai kerugian yang ditanggung bila Bendungan Ciawi runtuh.

Identifikasi awal dari skenario keruntuhan Bendungan Ciawi, kemungkinan disebabkan oleh piping dan atau overtopping. Ketika bendungan mengalami indikasi overtopping, maka biasanya dilakukan juga simulasi berdasarkan kondisi piping [5]. Namun karena bendungan ini difungsikan sebagai dry dam yang memiliki konduit banjir, kemungkinan besar dalam skenario hanya akan mengalami piping.

Kejadian banjir akibat keruntuhan Bendungan Ciawi yang dianalisis oleh program HEC-RAS v5.0.7 mungkin saja tidak sesuai dengan apa yang terjadi di lapangan. Karena para ahli menyatakan bahwa analisis keruntuhan bendungan sangat sulit disimulasikan secara simultan pada sisten sungai [6]. Walaupun begitu, hasil dari studi ini diharapkan dapat menjadi tambahan informasi dalam penyusunan peta potensi bencana banjir akibat keruntuhan Bendungan Ciawi.

\section{Bahan dan Metode}

\subsection{Bahan}

Data yang dibutuhkan guna menunjang studi ini adalah sebagai berikut :

a. Data Hujan Harian Maksimum Tahunan

Data hujan harian maksimum tahunan yang digunakan selama 35 tahun, dimulai dari tahun 1985 - 2019 guna menghitung debit banjir rancangan pada Bendungan Ciawi.

b. Data Teknis Bendungan

Data teknis Bendungan Ciawi untuk mengetahui karakteristik bendungan berupa tinggi bendungan, kapasitas bendungan, dan dimensi bendungan.

c. Lengkung Kapasitas Waduk

Lengkung kapasitas waduk merupakan gambaran tampungan di Waduk Ciawi yang digunakan dalam penelusuran banjir.

d. Peta Isohyet PMP Jawa Barat

Peta Isohyet PMP digunakan sebagai kontrol dari hujan PMP yang didapatkan dari perhitungan. Kedua hujan PMP akan dibandingkan dan diambil nilai yang lebih besar.

e. Peta DEM

Digunakan untuk melakukan simulasi pada perangkat lunak HEC-RAS 
f. Peta Rupa Bumi Indonesia (RBI)

Untuk mengetahui daerah mana saja yang terkena dampak dari keruntuhan Bendungan Ciawi.

g. Data Keterpaparan

Data berbentuk shapefile keterpaparan yang terdiri atas bangunan, jalan, dan tata guna lahan

h. Data Penduduk

Data penduduk terdampak untuk mengetahui penduduk terpapar akibat runtuhnya Bendungan Ciawi.

\subsection{Metode}

Studi dimulai dari analisis hidrologi yang datanya diuji oleh metode uji kualitas data hujan, analisis frekuensi, dan uji kesesuaian distribusi. Sehingga akan didapat curah hujan maksimum boleh jadi (PMP). Kemudian data hujan PMP dikonversi menjadi debit dengan metode Hidrograf Satuan Sintetis (HSS) yang pada akhirnya diperoleh nilai debit banjir rancangan PMF.

Selanjutnya data banjir disimulasikan melalui penelusuran banjir, yang mana akan diketahui apakah debit banjir tersebut akan membuat air di waduk mengalami overtopping atau tidak. Hasil tersebut lah yang disimulasikan ke dalam program HEC-RAS v5.0.7. Lalu sebaran genangan banjir akibat keruntuhan Bendungan Ciawi akan terlihat, dan dapat diketahui klasifikasi bahaya banjirnya.

Dari hasil sebaran genangan banjir, ditambah data ancaman dan keterpaparan, data dimasukkan pada program InaSAFE. Program InaSAFE secara otomatis menghitung kerugian dari data ancaman dan keterpaparan. Hasil akhir yang didapatkan berupa nilai kerugian total dalam rupiah akibat runtuhnya Bendungan Ciawi.

\subsection{Persamaan}

\section{- Debit Banjir Rencangan}

Hidrograf satuan digunakan dalam analisis menentukan banjir rancangan jika data yang tersedia merupakan data hujan. Metode ini relatif sederhana, mudah penerapannya, data yang diperlukan sederhana, dan hasil rancangan yang diberikan cukup teliti [7]

Persamaan HSS Nakayasu:

$$
\begin{array}{cc}
Q p=\frac{1}{3,6} \cdot A \cdot \frac{R o}{\left(0,3 T p+T_{0,3}\right)} & \text { Pers. } 1 \\
T p=T g+0,8 \mathrm{Tr} & \text { Pers. 2 } \\
T g=0,4+0,058 \mathrm{~L}, \text { untuk } L>15 \mathrm{~km} & \text { Pers. 3 } \\
T r=0,5 \text { tg sampai } 1 \mathrm{tg} & \text { Pers. 4 } \\
T 0,3=\alpha . \text { tg } & \text { Pers. 5 }
\end{array}
$$

dimana :

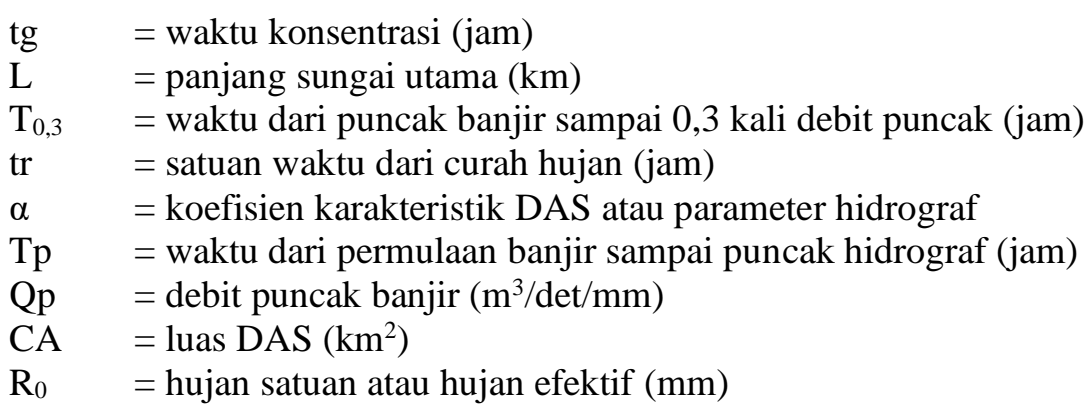


Persamaan HSS Gama I

$$
\begin{array}{cc}
Q t=Q p x e^{-\frac{t}{k}} & \text { Pers. } 6 \\
T R=0,43\left(\frac{L}{100 S F}\right)^{3}+1,0665 S I M+1,2775 & \text { Pers. } 7 \\
Q p=0,1836 A^{0.5886} \cdot T R^{-0.4008} \cdot J N^{0.2381} & \text { Pers. 8 } \\
T B=27.4132 T R^{0.1457} \cdot S^{-0.0986} \cdot S N^{0.7344} \cdot R U A^{0.2574} & \text { Pers. } 9 \\
K=0.5617 A^{0.1798} \cdot S^{-0.1446} \cdot S F^{-1.0897} \cdot D^{0.0452} & \text { Pers. } 10 \\
Q B=0.4751 A^{0.6444} \cdot D^{0.9430} & \text { Pers. } 11 \\
B=1.5518 A^{-0.1491} \cdot N^{-0.2725} \cdot S I M^{-0.0259} \cdot S^{-0.0733} & \text { Pers. } 12
\end{array}
$$

dimana :

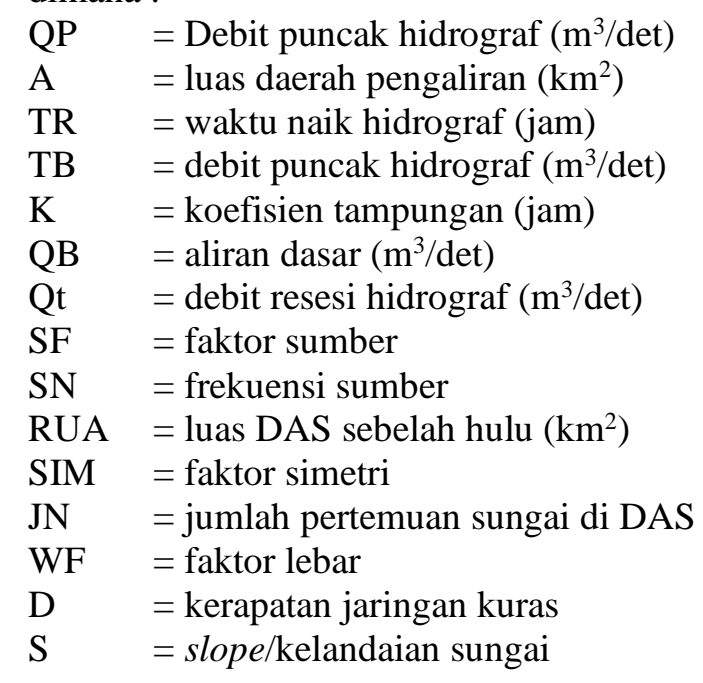

\section{- Penelusuran Banjir}

Bendungan Ciawi direncanakan sebagai pengendali banjir Sungai Ciliwung. Karena tampungan bendungan yang relatif kecil, perlu dilakukan rekayasa operasi dengan menerapkan konsep dry dam. Dimana pada awal musim hujan elevasi muka air waduk diatur rendah, sehingga pada awal banjir debit banjir mengalir bebas melewati konduit [8]. Menyesuaikan dengan kebutuhan sebagai pengendali banjir, maka konsep pengendalian banjir pada Bendungan Ciawi sebagai berikut :

- Mengubah pola aliran sungai eksisting yang melalui saluran alam menjadi aliran terkontrol melalui terowongan.

- Kapasitas pengeluaran melalui terowongan akan lebih kecil dibanding saluran alam, sehingga air yang masuk ke Bendung Katulampa lebih kecil.

- Menahan naiknya elevasi muka air akibat debit outflow yang lebih kecil dari debit inflow.

- Bendungan dilengkapi pelimpah, sehingga ketika debit banjir besar, air dapat mengalir melalui pelimpah. Debit yang keluar di hilir merupakan gabungan debit terowongan dan pelimpah.

Oleh karena itu, berdasarkan pola operasi Bendungan Ciawi, maka dalam studi ini penelusuran banjir dilakukan pada debit $\mathrm{Q}_{\mathrm{PMF}}$ dengan simulasi gabungan pelimpah dan konduit banjir berbentuk tapal kuda termodifikasi. Terdapat tiga kondisi aliran sungai dalam konsep pengendalian banjir yang dapat dilihat pada (Gambar. 1, 2 dan 3) dengan penjelasan sebagai berikut :

1. Kondisi 1 : ketika debit sungai lebih rendah dari kapasitas terowongan, maka tinggi muka air di terowongan lebih rendah atau sama dengan tinggi terowongan. Air mengalir dalam kondisi aliran bebas. 
2. Kondisi 2 : ketika debit sungai melampaui kapasitas terowongan, air naik tetapi masih di bawah mercu pelimpah. Air mengalir dalam kondisi aliran tekan.

3. Kondisi 3 : ketika debit banjir melampaui kapasitas terowongan, air naik dan melampaui elevasi mercu pelimpah. Air mengalir melalui terowongan dalam kondisi aliran tekan dan melimpas melalui mercu pelimpah.

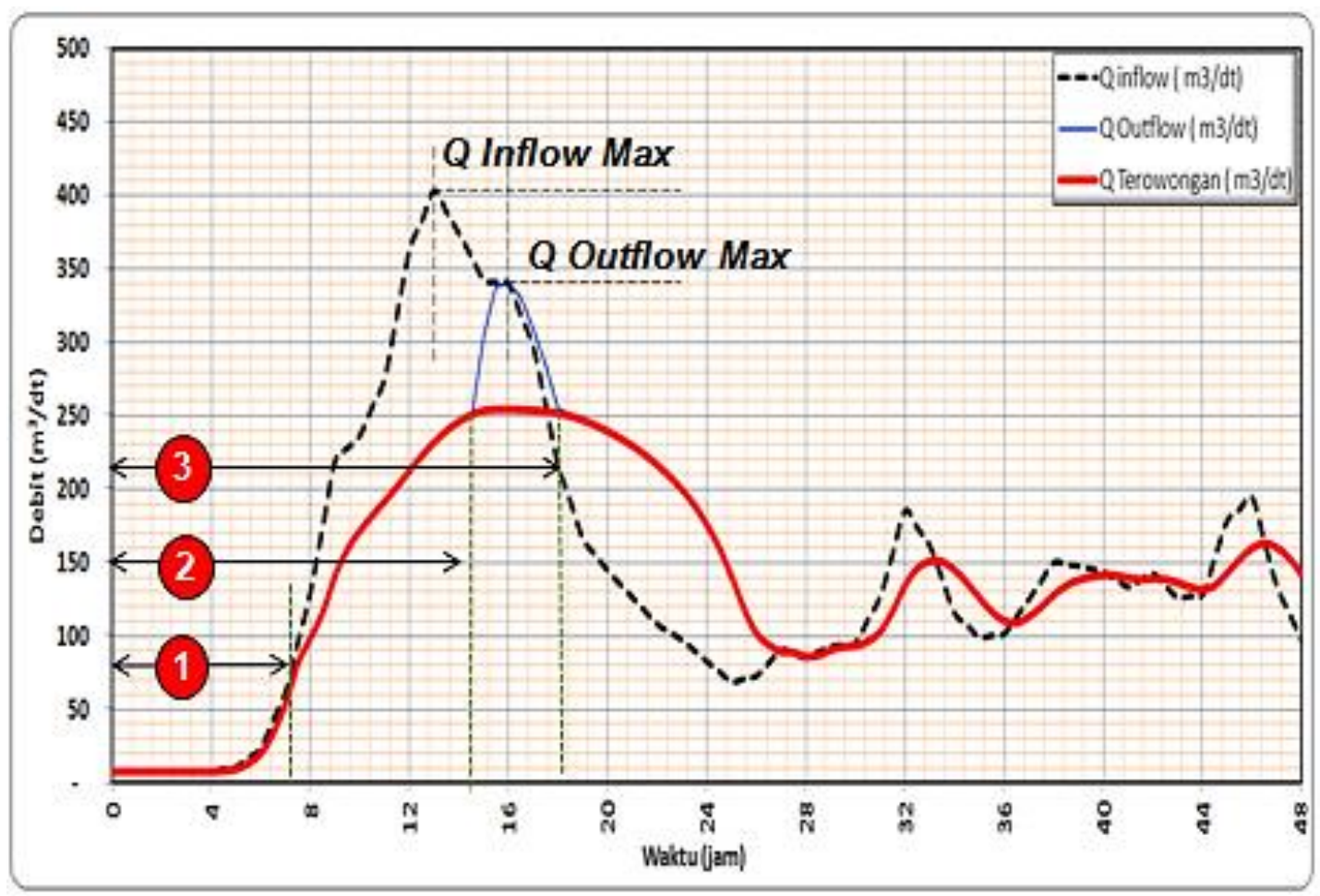

Gambar 1 : Grafik Debit terhadap Waktu dalam Konsep Penelusuran Banjir Gabungan Pelimpah dan Konduit Banjir

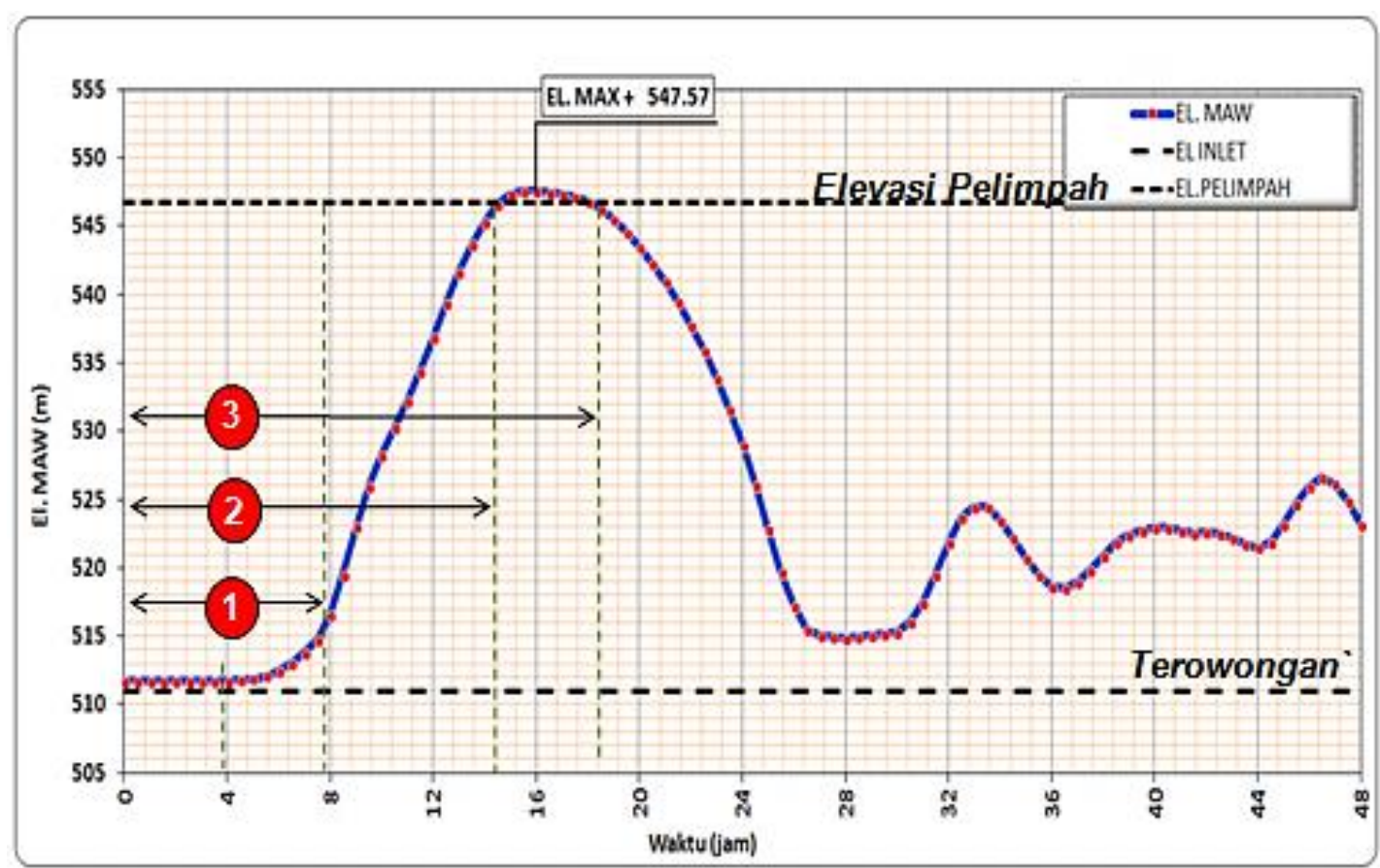

Gambar 2 : Grafik Elevasi Muka Air Waduk terhadap Waktu dalam Konsep Penelusuran Banjir Gabungan Pelimpah dan Konduit Banjir 


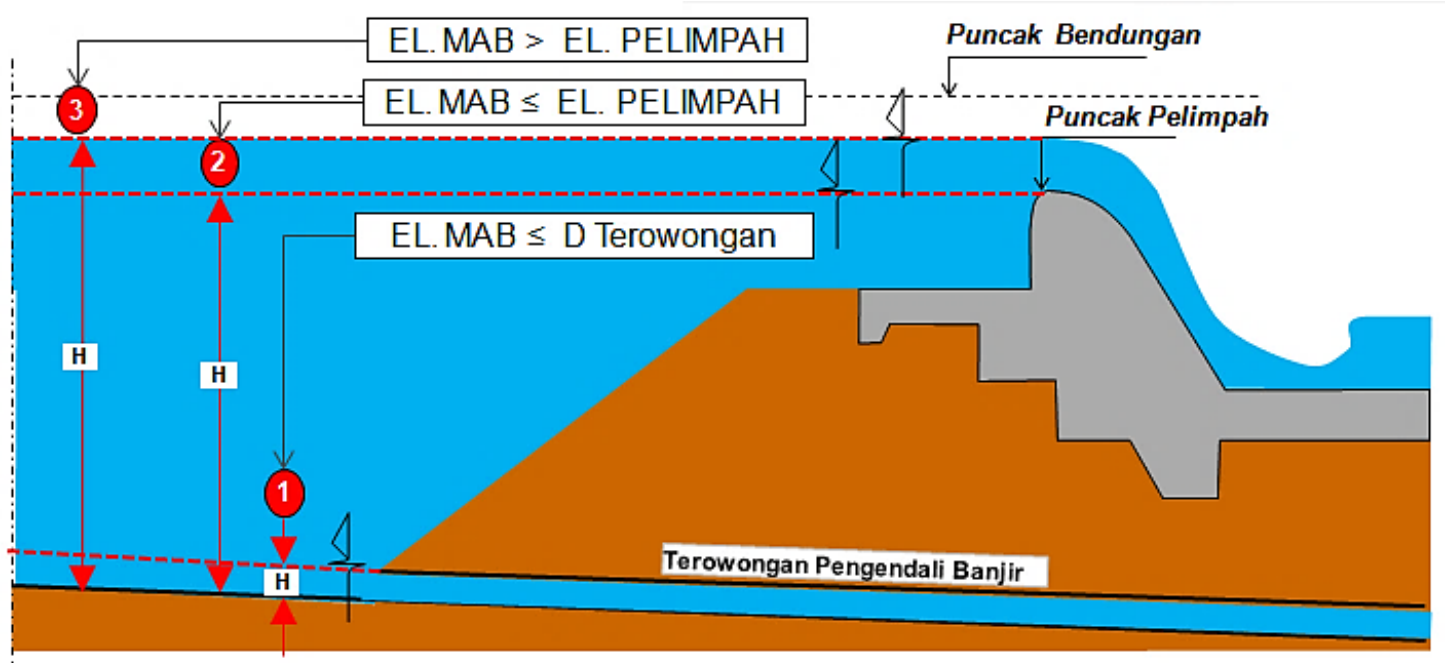

Gambar 3 : Konsep Penelusuran Banjir Gabungan Pelimpah dan Konduit Banjir

\section{- Keruntuhan Bendungan}

Menurut laporan Komisi Internasional Bendungan Besar, keruntuhan bendungan urugan terjadi $38 \%$ akibat piping, $35 \%$ akibat overtopping, $21 \%$ akibat kegagalan pondasi, dan $6 \%$ lain-lain [9]. Oleh karena itu pada studi ini keruntuhan bendungan hanya berdasarkan skenario piping (Gambar. 4) dan atau overtopping (Gambar. 5).

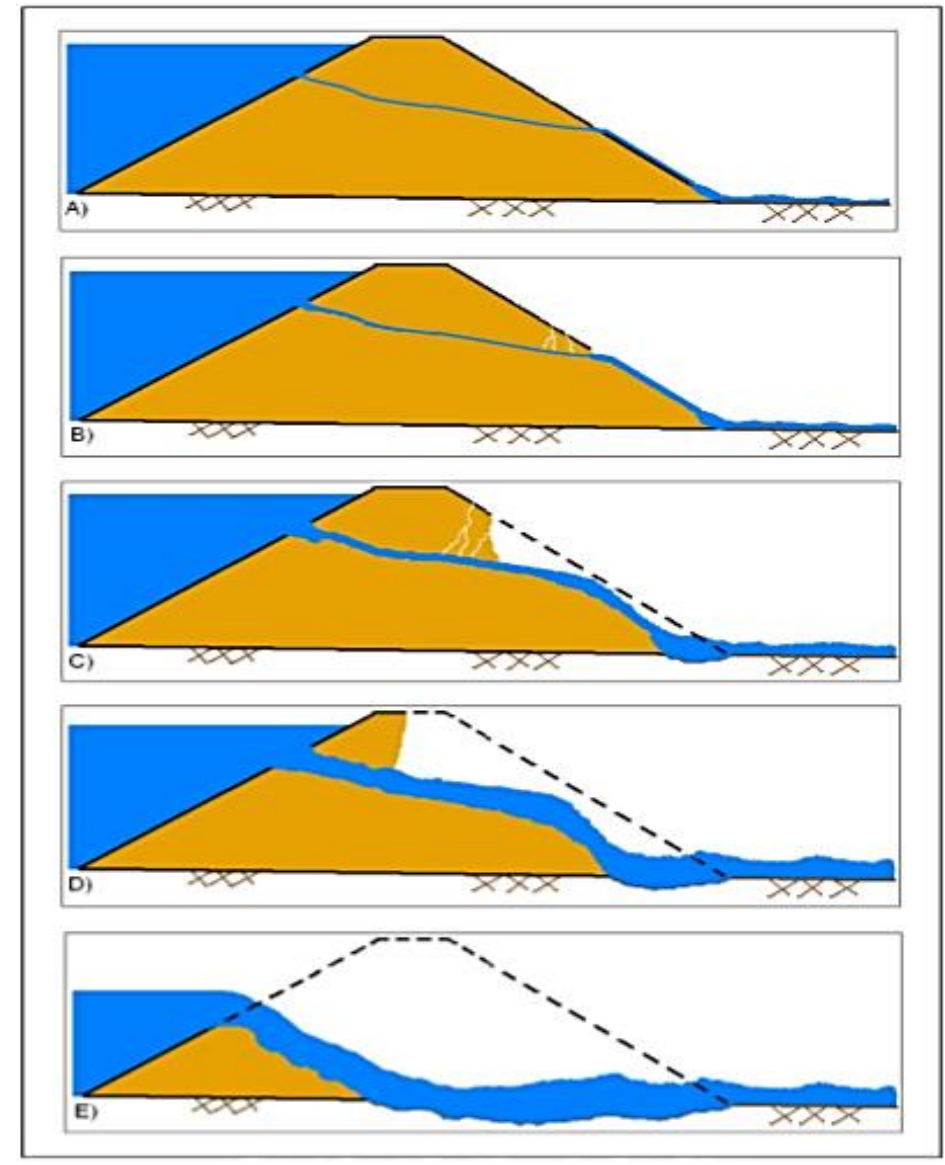

Gambar 4 : Proses Keruntuhan Bendungan Akibat Piping 


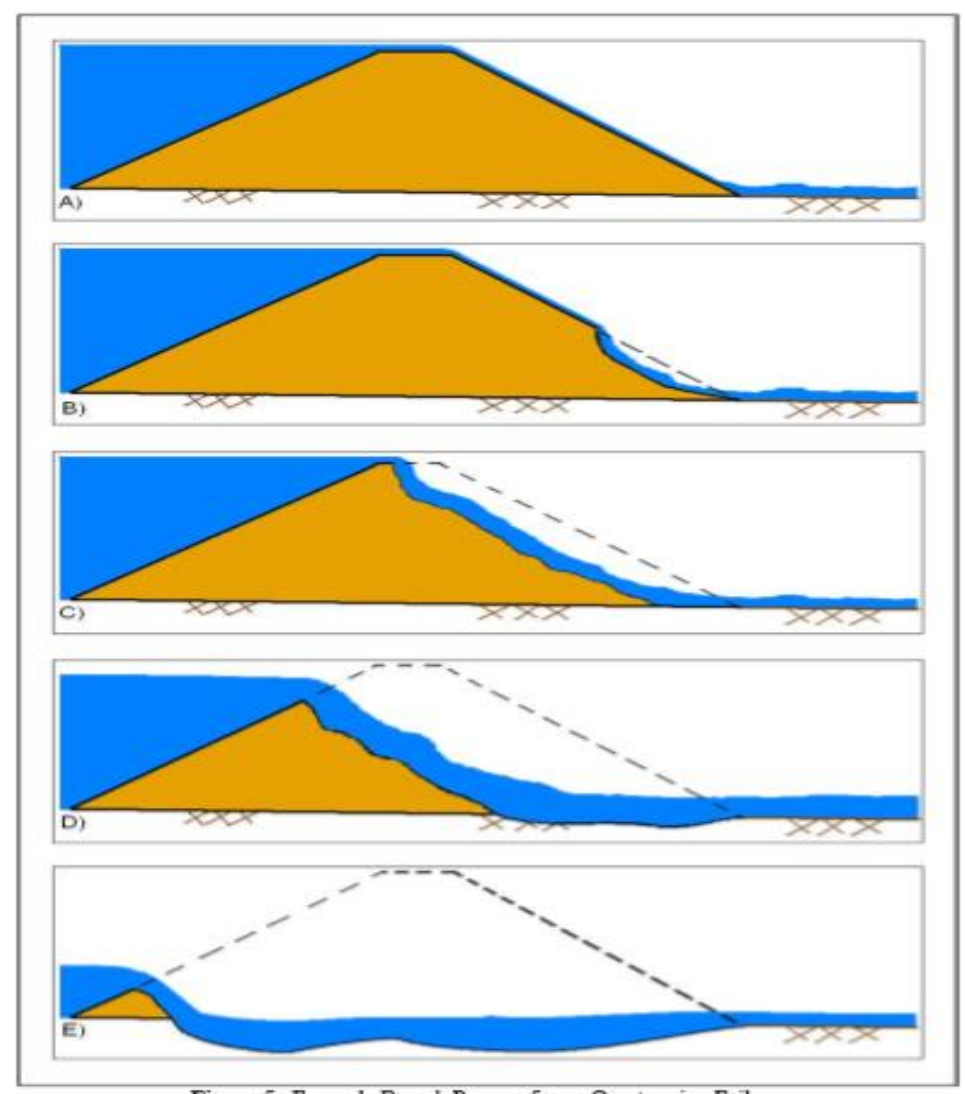

Gambar 5 : Proses Keruntuhan Bendungan Akibat Overtopping

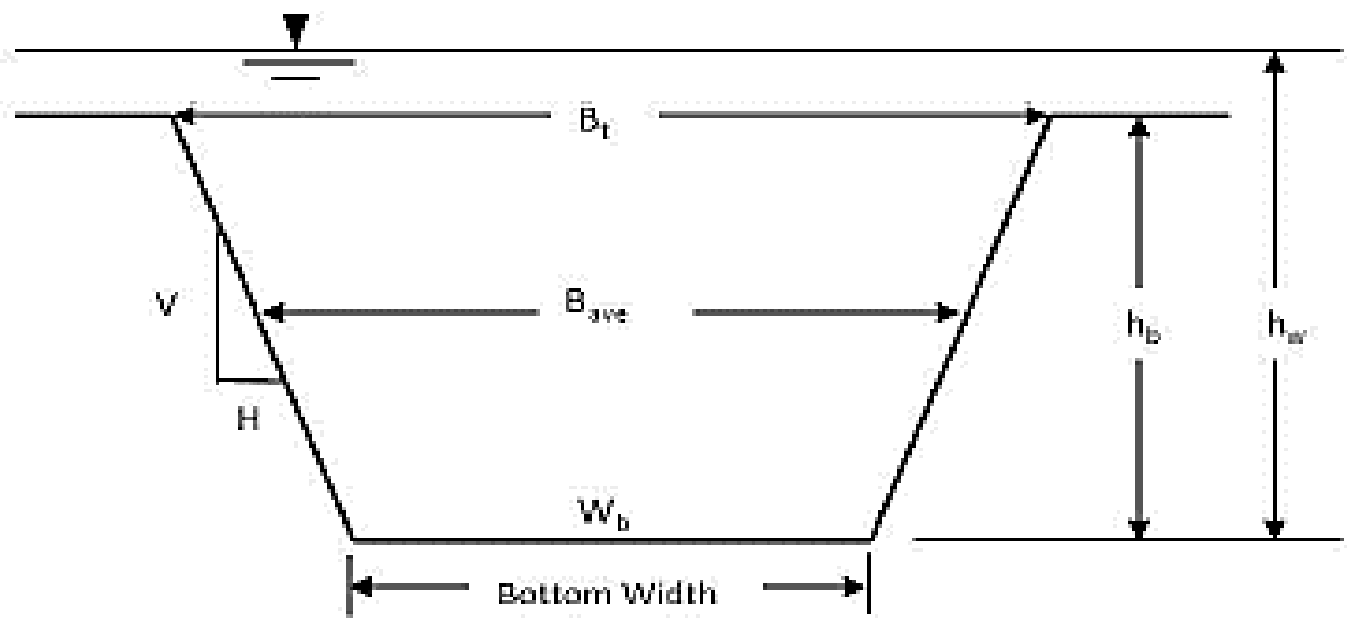

Gambar 6 : Gambaran Parameter Rekahan

Sebelum bendungan mengalami keruntuhan total, didahului oleh terjadinya rekahan (breaching) (Gambar. 6) [10]. Persamaan regresi Froechlich (2008) untuk lebar rata-rata rekahan dan waktu keruntuhan adalah sebagai berikut:

$$
\begin{gathered}
B_{a v e}=0.27 K_{0} \cdot V w^{0,32} \cdot h b^{0,04} \\
t f=63.2 \sqrt{\frac{V w}{g h b^{2}}}
\end{gathered}
$$

Pers. 14

dimana:

Bave = lebar rata-rata rekahan $(\mathrm{m})$ 
$\mathrm{K} 0=$ konstanta $(1,3$ untuk keruntuhan overtopping , 1,0 untuk piping)

$\mathrm{VW}=$ volume tampungan saat keruntuhan $\left(\mathrm{m}^{3}\right)$

$\mathrm{hb} \quad=$ tinggi akhir rakahan $(\mathrm{m})$

g = persamaan gravitasi $\left(9,80665 \mathrm{~m} / \mathrm{s}^{2}\right)$

tf $\quad=$ waktu keruntuhan (detik)

Froechlich menyatakan bahwa lereng sisi rata-rata seharusnya $1.0 \mathrm{H}: 1 \mathrm{~V}$ untuk keruntuhan overtopping dan $0,7 \mathrm{H}: 1 \mathrm{~V}$ untuk keruntuhan lainnya (seperti piping).

\section{- Perangkat Lunak HEC-RAS}

HEC-RAS (Hydrologic Engineering Center's River Analysis System) adalah perangkat lunak yang memungkinkan untuk melakukan simulasi hidraulik aliran satu dimensi, melakukan perhitungan aliran sungai tidak seragam satu atau dua dimensi, melakukan model pergerakan sedimen dalam aliran tidak seragam dan aliran tidak seragam penuh, melakukan analisis suhu air, dan melakukan pemodelan kualitas air secara umum.

Terdapat 5 langkah utama dalam menciptakan model hidrolik dengan HEC-RAS:

1. Memulai proyek baru

2. Memasukkan data geometris

3. Memasukkan data aliran dan kondisi batas

4. Melakukan perhitungan hidraulik

5. Melihat dan mencetak hasil

\section{- Klasifikasi Tingkat Bahaya Bendungan menggunakan InaSAFE}

Penentuan klasifikasi tingkat bahaya bendungan dalam perangkat lunak InaSAFE merujuk pada Peraturan Kepala BNPB No. 02 Tahun 2012, tingkat ancaman dihitung menggunakan hasil klasifikasi ancaman dan klasifikasi penduduk terpapar yang dihubungkan dengan matriks (Gambar. 7) berikut :

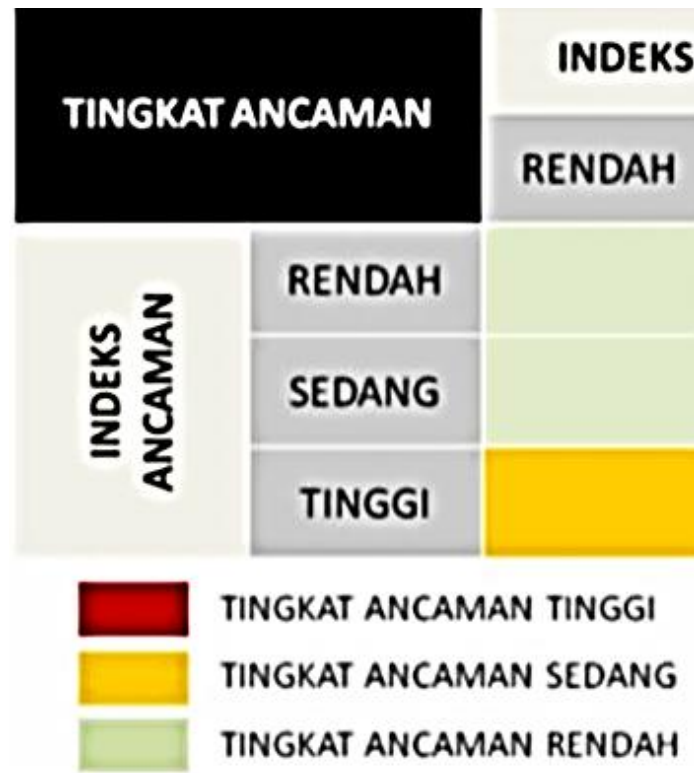

Gambar 7 : Matriks Penentuan Tingkat Bahaya

\section{Hasil dan Pembahasan}

\subsection{Analisis Hidrologi}

Berdasarkan Peta PMP Isohyet Jawa Lembar 1, nilai PMP yang terjadi di lokasi Bendungan Ciawi sebesar 725,00 mm/hari. Karena nilai PMP peta lebih besar dari nilai PMP hitung (725,00 > 709.690), perhitungan selanjutnya digunakan nilai PMP tertinggi yaitu sebesar 725,00 mm/hari. 
Tabel 1 : Rekapitulasi Nilai Hidrograf Satuan Sintesis

\begin{tabular}{ccc}
\multirow{2}{*}{ Metode HSS } & \multicolumn{2}{c}{ Debit Banjir Rancangan $\left(\mathrm{m}^{3} / \mathrm{dt}\right)$ Kala Ulang Tertentu } \\
\cline { 2 - 3 } & 1000 th & PMF \\
\hline Nakayasu & 815,216 & 1845,867 \\
Gama I & 696,319 & 1592,089 \\
\hline
\end{tabular}

Berdasarkan (Tabel. 1) di atas, diketahui nilai debit banjir rancangan metode HSS Nakayasu lebih besar dibanding metode HSS Gama I. Oleh karena itu yang akan digunakan adalah debit banjir rancangan metode HSS Nakayasu dengan Q $_{1000}$ sebesar 815,216 m³/detik dan QPMF sebesar 1845,867 $\mathrm{m}^{3} /$ detik.

3.2 Penelusuran Banjir Kombinasi Konduit Tapal Kuda Termodifikasi dengan Pelimpah

Dari hasil flood routing $\mathrm{Q}_{\mathrm{PMF}}$ (Gambar. 8), diketahui elevasi maksimum +547,534 m, dimana sudah melewati pelimpah yang berada pada elevasi $+546,75 \mathrm{~m}$. Dengan puncak bendungan berada di elevasi $+551,00 \mathrm{~m}$, pada kondisi banjir QPMF tidak mengalami overtopping.

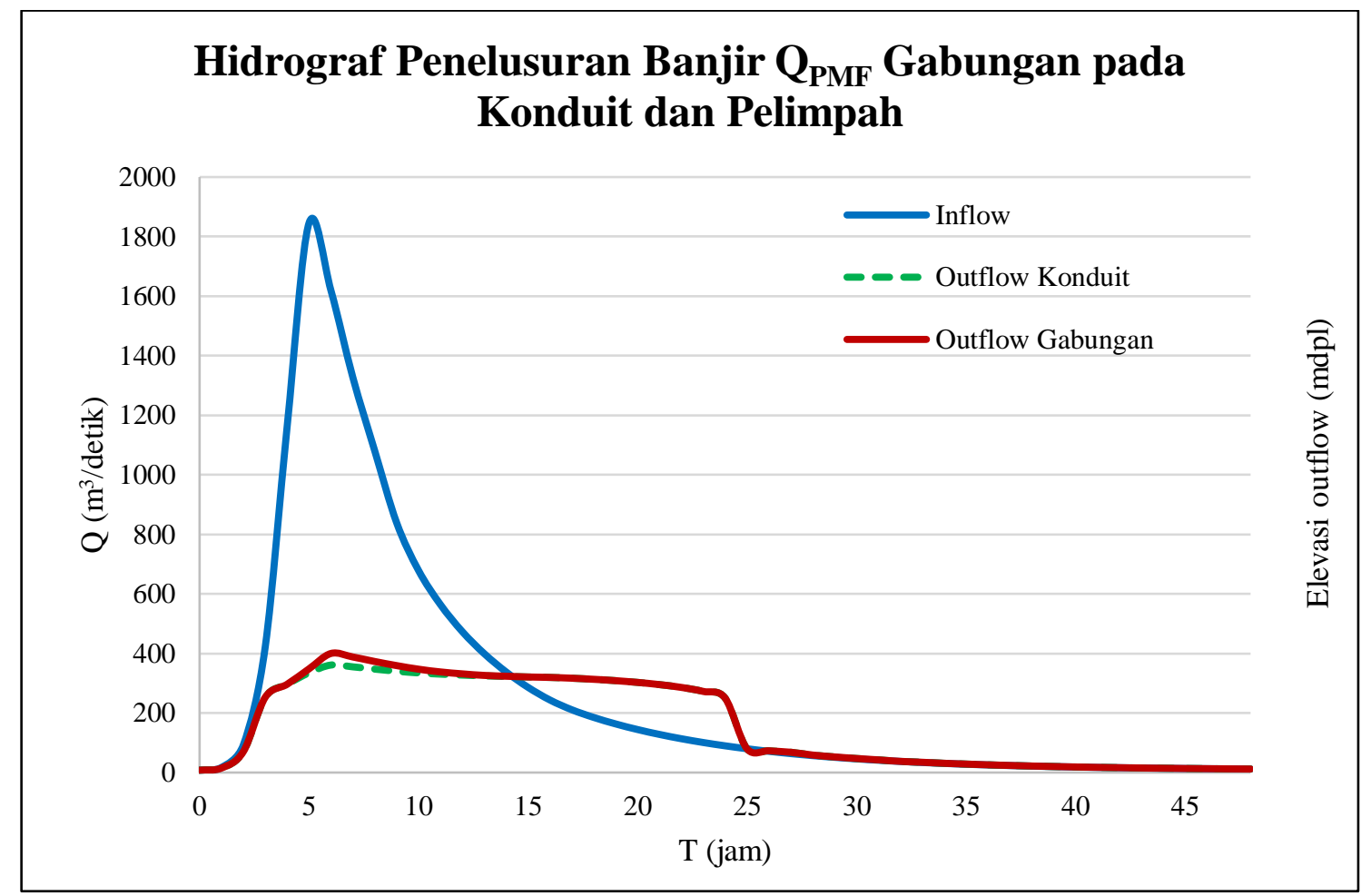

Gambar 8 : Grafik Hubungan Inflow Outflow pada Konduit dan Pelimpah QPMF

\subsection{Output Simulasi HEC-RAS}

Karakteristik banjir akibat keruntuhan Bendungan Ciawi berbeda untuk setiap kejadian. Karakteristik banjir dapat dilihat dari gambar sebaran itu sendiri (Gambar. 9) maupun tabel (Tabel. 2) atau juga dapat dilihat dengan membuat garis cross section atau long section pada sebaran banjir di menu RAS-Mapper.

Tabel 2 : Luas Genangan Banjir Akibat Keruntuhan Bendungan Ciawi

\begin{tabular}{ccc} 
Kejadian keruntuhan & Luas $\left(\mathrm{m}^{2}\right)$ & Luas $\left(\mathrm{Km}^{2}\right)$ \\
\hline \hline Piping Atas MAB & 98981583,056 & 98,98 \\
Piping Tengah MAB & 106449176,778 & 106,45 \\
Piping Bawah MAB & 108038715,636 & 108,04 \\
\hline
\end{tabular}




\begin{tabular}{ccc}
\hline Piping Atas MAN & 96413263,530 & 96,41 \\
Piping Tengah MAN & 104915004,047 & 104,92 \\
Piping Bawah MAN & 104693519,108 & 104,69 \\
\hline
\end{tabular}

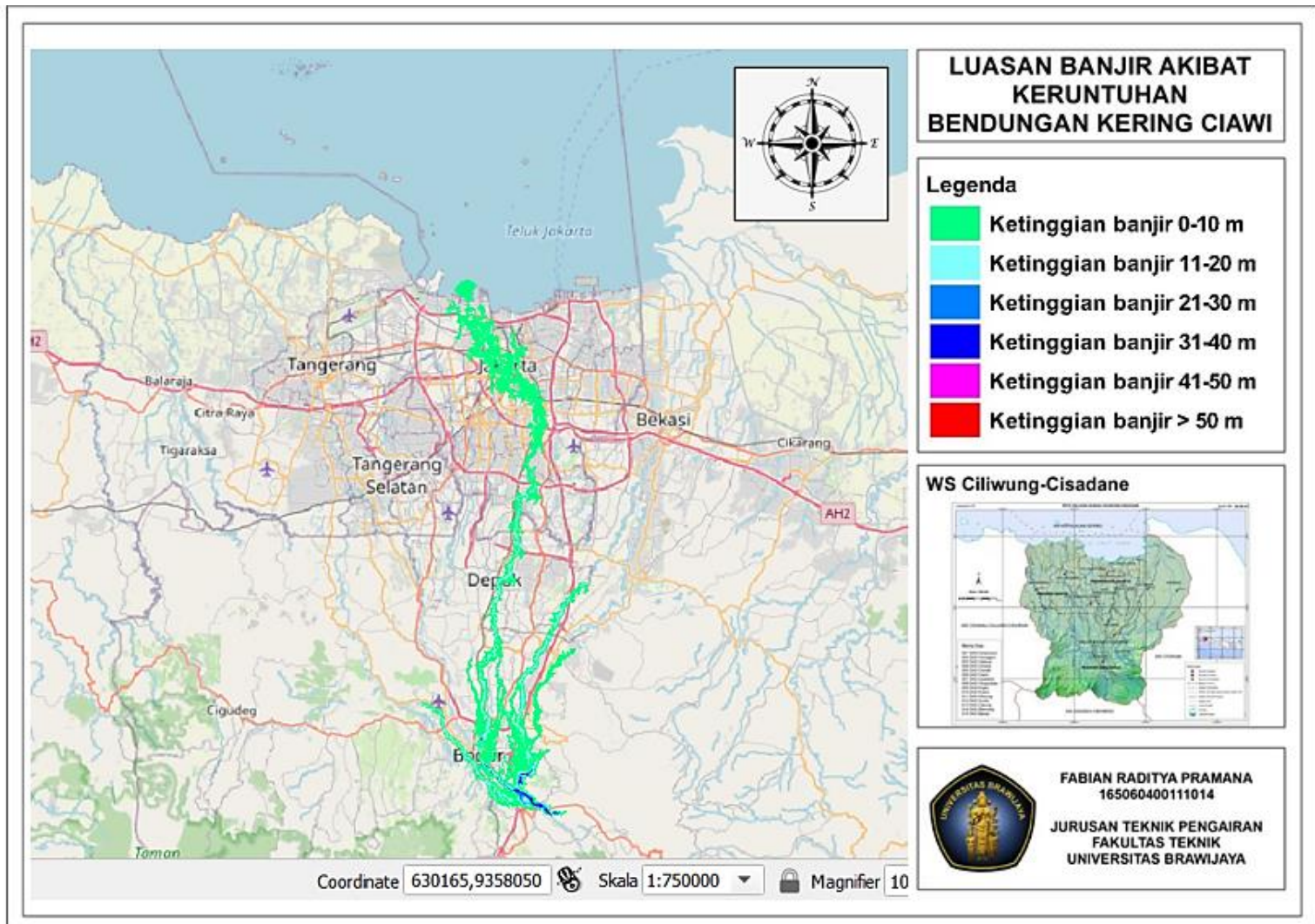

Gambar 9 : Genangan Banjir Keruntuhan Bendungan Ciawi Akibat Piping Bawah MAB

Dari (Gambar. 9) dan (Tabel. 2), dapat diketahui bahwa keruntuhan Bendungan Ciawi akibat piping bawah muka air banjir mengakibatkan luasan genangan banjir paling besar dengan luas 108,04 km².

Tabel 3 : Kecepatan Maksimum Akibat Keruntuhan Bendungan Ciawi

Kejadian Keruntuhan Kecepatan Maksimum

\begin{tabular}{cc} 
& $(\mathrm{m} /$ detik$)$ \\
\hline \hline Piping Atas MAB & 64,324 \\
Piping Tengah MAB & 114,268 \\
Piping Bawah MAB & 97,788 \\
Piping Atas MAN & 93,345 \\
Piping Tengah MAN & 94,745 \\
Piping Bawah MAN & 112,336 \\
\hline
\end{tabular}

Dari (Tabel. 3) tersebut dapat diketahui bahwa besarnya kecepatan akibat keruntuhan Bendungan Ciawi saat piping sangat beragam. Hal ini kemungkinan dapat terjadi lantaran data yang dimasukkan ke dalam program HEC-RAS juga beragam, sehingga hasil dari simulasi tidak dapat dijelaskan secara akurat.

3.4. Klasifikasi Tingkat Bahaya Bendungan

Dari analisis keruntuhan Bendungan Ciawi, didapat tinggi genangan maksimum 46,419 m. dimana menurut perangkat lunak InaSAFE yang mengacu pada Peraturan Kepala BNPB No. 02 Tahun 2012, untuk banjir di atas 3 meter dikategorikan klasifikasi bahaya tingkat tinggi. 


\subsection{Analisis Kerugian}

Dari analisis kerugian yang dilakukan meliputi bangunan, jalan, tata guna lahan, penduduk, dan kebutuhan evakuasi didapatkan kerugian sebesar Rp. 2.590.191.888.693.

\section{Kesimpulan}

Berdasarkan simulasi, debit banjir rancangan dengan kala ulang QPMF 1845,867 $\mathrm{m}^{3} / \mathrm{dt}$ tidak menyebabkan Bendungan Ciawi overtopping, sehingga skenario dianggap hanya mengalami piping, dimana kondisi paling ekstrem yakni piping bawah muka air banjir. Dengan kedalaman banjir yang besar, maka banjir akibat keruntuhan Bendungan Ciawi dikategorikan sebagai bahaya tingkat tinggi.

\section{Daftar Pustaka}

[1] B. Harsoyo, "Mengulas Penyebab Banjir di Wilayah DKI Jakarta dari Sudut Pandang Geologi, Geomorfologi dan Morfometri Sungai," Jurnal Sains \&amp; Teknologi Modifikasi Cuaca, vol. 14, no. 1, p. 37, 2013.

[2] D. Wirustyastuko and J. Nugroho, "Analisis Wilayah Tergenang dan Perilaku Banjir pada Simulasi Kegagalan Bendungan Ciawi,” Jurnal Teknik Sipil, vol. 20, no. 2, p. 121, 2013.

[3] S. G. Aniskurlillah, P. T. Juwono, R. Asmaranto, "Analisa Keruntuhan Bendungan Muka Kuning Batam Menggunakan Aplikasi ZHONG XING HY21,” Jurnal Teknik Pengairan

[4] P. I. Purwanto, P. T. Juwono, and R. Asmaranto, "Analisa Keruntuhan Bendungan Tugu Kabupaten Trenggalek,” Jurnal Teknik Pengairan, vol. 8, no. 2, pp. 222-230, 2017.

[5] E. V. Aryadi, P. T. Juwono, D. Priyantoro, and R. Asmaranto, "Analisa Keruntuhan Bendungan Gondang dengan Menggunakan Program ZHONG XING HY21," Jurnal Teknik Pengairan, vol. 5, no. 1, pp. 110-118, 2014.

[6] M. Adhi, P. T. Juwono, and M. Sholichin, "Analisa Keruntuhan Bendungan Mamak dan Bendungan Batu Bulan Secara Simultan pada Sistem Pengaliran Sungai Denditrik," Jurnal Teknik Pengairan, vol. 7, no. 1, pp. 47-60, 2016.

[7] B. Triatmodjo, Hidrologi Terapan. Yogyakarta: Beta Offset, 2008

[8] Y. Astuti, Laporan Pendukung Hidrologi Pekerjaan Detail Desain Bendungan Ciawi dan Bendungan Sukamahi. Malang: PT Indra Karya, 2015

[9] S. M. Barghouti, L. M. G. J.-M, and Plusquellec Hervé, Dam Safety and the Environment. Washington, D.C: World Bank, 1990.

[10] A. Murdhianti, P. T. Juwono, and R. Asmaranto, "Mitigasi Bencana Banjir Akibat Keruntuhan Bendungan Berdasarkan Dambreak Analysis pada Bendungan Benel di Kabupaten Jembrana," Jurnal Teknik Pengairan, vol. 7, no. 2, pp. 193-204, 2016. 